\title{
The Implementation of Big Book as Media to Teach Reading Comprehension for the Sixth Grade Students of Elementary School
}

\author{
Ni Wayan Surya Mahayanti ${ }^{1}$, Ni Ketut Ayu Asrina ${ }^{2}$ \\ English Education Department \\ Universitas Pendidikan Ganesha \\ Singaraja, Indonesia \\ mahayantisurya@yahoo.co.id ${ }^{1}$, ayuasrina516@gmail.com²
}

\begin{abstract}
Since big book becomes one kind of tools which can facilitate students' comprehension during reading stories activities conducted by teachers, this study aimed to know the implementation of Big Book in improving students' reading comprehension of the sixth-grade students. Descriptive Qualitative was used with the sixth-grade students as the subject in this study. The instruments used in this study were a video recorder, teacher's diary, and interview guide. The data were collected through observations and interviews. The result of this study showed that the implementation of Big Book was very helpful for improving students' reading comprehension.
\end{abstract}

Keywords—big book, media, reading comprehension, young learner

\section{INTRODUCTION}

English is a foreign language that the students should acquire from the early age [1], [2]. Starting to learn English at the early age is good to enhance the learner skills [2]. There are four skills that students should acquire in learning English. One of them is reading. It is stated that reading becomes one of the important parts in acquiring language acquisition since most of the subject matters in the school begin with printed material or text book and most of the students' tasks are related to reading activity [3].

Furthermore, reading is an interactive process between the reader and the text [4]. The process involves the interaction of the reader with the text and constructing the meaning through various kind of knowledge. The knowledge can be the topic of the text, the main idea of the text, the grammatical structure of the language which used in the text, and also the symbol in the text. Thus, comprehension becomes the primary purpose of reading [5]. When we read, we need to understand what the writer intended to convey in writing. Moreover, reading comprehension is not as simple as reading the text and the reader can find the meaning directly. It is a process of relating previous knowledge and the information found in text in order to construct the meaning of the text [6] [7]. By relating the readers' background knowledge and the text itself, they will comprehend the text well. In reading comprehension, the students are expected to be able to recall word meanings, draw inferences about the meaning of a word in context, finding answers to questions answered explicitly or in paraphrase, and weaving ideas in the content [8] [9].

In fact, the students are still struggling to comprehend the reading text. It matched with the facts that the researcher found as the result of pre-observation and informal interview with the teacher and students in SD Laboratorium Undiksha Singaraja. Most of the students looked confused and uninterested when the teacher distributed reading text, then asked the students to read the text and answered the questions based on the text. The students said that they did not understand what the text was about. There were so many difficult words in the text. The students just wait for the teacher to explain the meaning of those words for them without any effort to check it in the dictionary. Furthermore, in answering the questions, most of the students just guess the answer because they could not grasp what the text was about. It is obvious that the students in SD Laboratorium Undiksha Singaraja encountered the difficulties in finding the main idea, specific information, word meaning, and textual reference in the text. In addition, the teacher seemed too reliant on the use of conventional media in teaching reading. It made the students feel bored and did not give the positive response in the learning activity.

Teaching reading for young learners is not easy and quite challenging. Teaching reading for young learners needs special way because young learners have special characteristics. The learners at age of 7-12 years are categorized as young learners who have some special characteristics that the teacher must consider [10]. One of the characteristics of young learners is the short attention span in which if the teacher cannot consider it well, they tend to easily get bored [10]-[12]. Young learners will lose their interest after ten minutes or so, so the teacher must be good in getting students' attention and make them not feel bored in the reading lesson. In teaching reading for young learners, the teacher needs attractive media in order to make them easy to 
understand the text because using appropriate media is one of the key principles to create the effective learning process [13].

Media, in order to accomplish effective lessons, are defined as means or tools that can be used to transfer the content of the materials to the learners [14]. Additionally, by using media the learners will engage in the learning process and it can help the teacher to get the students' attention in the learning process. By using media in teaching English to young learners, the teachers can easily provide a good classroom situation [12]. A good media can attract students' attention and make the students focus on the learning process. One of the media that can be used to teach reading for young learners is a story in form of Big Book.

It is described by Hall \& O'Connor that big book is a large format of printed book with texts and illustrations [16]. Big Book is kind of storybook that printed in a large version. Reading a big book is one of the activities used to facilitate students' comprehension of a story delivered by the teacher [17]. They add, the big book helps the students to learn new vocabulary and to enhance students' reading comprehension of a text. There are some benefits of using Big Book in the classroom such as Big Book creates secure and relaxed atmosphere in the classroom and attracts students' attention in the learning process, Big Book attracts young learners curiosity as well as sustains their enthusiasm, Big Book stimulates students' imagination and helps students' in understanding the story, and Big Book improves students' attention and participation in reading class [18]. Thus, the big book is a good medium to help the elementary school students in comprehending the reading text.

As mentioned in [19], in implementing the big book, there are some activities that should be conducted, they are prereading activity before reading the big book, reading the complete story, re-reading activity, after reading activity, and close activity. In the pre-reading activity, the teacher shows the front cover, pages, the upper part, and the bottom part of Big Book, the back cover and how to open the book in the right way. By showing the front cover, it will create a conducive to get a great discussion with the learner by giving a comment on the illustration or the picture with the word on the front cover. The teacher tells the title of the book, the writer of the big book, and the illustrator of the big book loudly. Then, they ask about the possible story of the book based on the title and the illustration on the front cover of the book. Then, in reading the complete story, the teacher read the story continuously from the first page until the last page. The teacher read the story loudly along with interesting expressions and intonation. The teacher can stop on a certain page and ask the children to guess the text in the next page or give additional information about the story or the illustration. After that, in re-reading activity, the teacher repeats the story page by page. The teacher shows the words and says it clearly. The teacher asks the comment from the children about the story and stops for a while in the certain page to give a chance to the children to memorize and guess the next words in the story. Moreover, in after reading activity, the teacher discusses the keyword in the story and helping the learner to connect one concept with another concept. Then, the teacher and children read the story together. The teacher gives stressing in the way to read and gives a correction about the way to read in a comfortable way. Last, in close activity, the teacher gives various types of interesting activities based on the area. The teacher can give guessing word game, bolding the words game, arranging the words game, completing the missing words, coloring picture, drama playing, pantomime, imitating certain character in Big Book, putting the number to the picture, storytelling, and much more based on the area.

A study on the use of big book has been conducted by Fahmi, Suhartono, \& Arifin in 2013 in the fifth-grade students of SDN 32 Pontianak. This study focused on the use of the big book in improving students' reading comprehension. The result of this study showed that the use of the big book in improving students' reading comprehension can be seen in every meeting or cycles [18]. Another research has been done by Suantari in 2016 in SD Laboratorium UNDIKSHA Singaraja in developing the big book in teaching English at sixth-grade students based on the syllabus in SD Laboratorium Undiksha Singaraja. This study was Research and Development and the result of this research showed that the Big Book developed was categorized as excellent media [20]. Since it has not been implemented yet in order to know how well the implementation of the big book could help the students' reading comprehension, it is a need to continue the research in implementing that media in teaching reading for students of elementary school.

In this present study, Big Book was applied in order to know the implementation of Big Book for improving the sixth-grade students reading comprehension. This study was a descriptive qualitative study in which the purpose of this study was to know the implementation of Big Book on the sixthgrade students' reading comprehension. This study conducted in the sixth grade of elementary school students in SD Laboratorium Undiksha Singaraja in academic year $2016 / 2017$.

\section{RESEARCH METHOD}

This study was descriptive qualitative Study. The subject of this study was the sixth-grade students of SD Laboratorium Undiksha Singaraja. There were two classes of the sixth-grade students of SD Laboratorium Undiksha Singaraja, and one class was used as the subject of the study that consisted of 35 students. The object of this study was big book which was used to teach reading comprehension. The instruments used in this study were video recorder and teacher's diary. The recorder was used to record all the activities during the implementation of Big Book as media while Teachers' Diary was used to monitor the result of the implementation of Big Book as media on students' reading comprehension. The data were collected through observations and interview. 


\section{FINDING AND DISCUSSION}

In this study, the implementation of Big Book was conducted six times for the sixth-grade students. The researcher used three Big Books in this study. The theme of the first Big Book was about seasons entitled Bibbie's Seasons Adventure. Then, the theme of the second Big Book was about tourism entitled Riry Rabbit's Dream Holiday. The last theme of the Big Book was about directions entitled Follow Me. In the application of Big Book as media, there were some activities done by the researcher as stated in applying the Big Book [19]. There is pre-reading activity before reading the big book, reading the complete story, re-reading activity, after reading activity, and close activity. During the treatments that had been conducted, the media was applied systematically based on the procedures.

In the beginning of the teaching learning process, students who were taught by using Big Book as media were asked to make a circle in front of the teacher. Then, the researcher started the pre-reading activity before reading Big Book. In this pre-reading activity, the researcher introduced the parts of Big Book such as the front cover, pages, the upper part, and the bottom part of the Big Book, the back cover and how to open the book in the right way. The researcher told the title of the book, the writer of the Big Book, and the illustrator of the Big Book loudly to make the students know about the Big Book. This activity was used to activate the students' prior knowledge related to the story. Then, the students were asked about the possible story of the Big Book based on the title and the illustration on the front cover of the book. The illustration of the Big Book helped the students in constructing the meaning of the story by seeing the picture on the Big Book. Therefore, the students interpret the stories from the pictures. In this activity, the students seemed really enthusiastic to see the Big Book and Big Book can attract students' attention. This is in line with the statement by Nambiar who states that one of the advantages of Big Book was Big Book can attract students' attention because of the unusual size [21]. The following pictures show the front cover of the big book used.

The second activity was reading the complete story. In this activity, the researcher read the story from the first page until the last page of the Big Book continuously. It was done to make the students familiar with the story and encourage them to read independently. The researcher read the story loudly along with the interesting expressions and intonation. Using interesting expressions and intonation made the students focus on the story and it also made them enthusiastic in listening to the story. The researcher stopped on a certain page and asked the students to guess what would be on the next page. It used to check the students' understanding of the story. The students were active and enthusiastic to give their opinions about what would be on the next page of the Big Book. Moreover, the researcher gave additional information about the story or the illustration of the Big Book in order to help the students in understanding the story of the Big Book. The example of pages can be seen in the following picture.

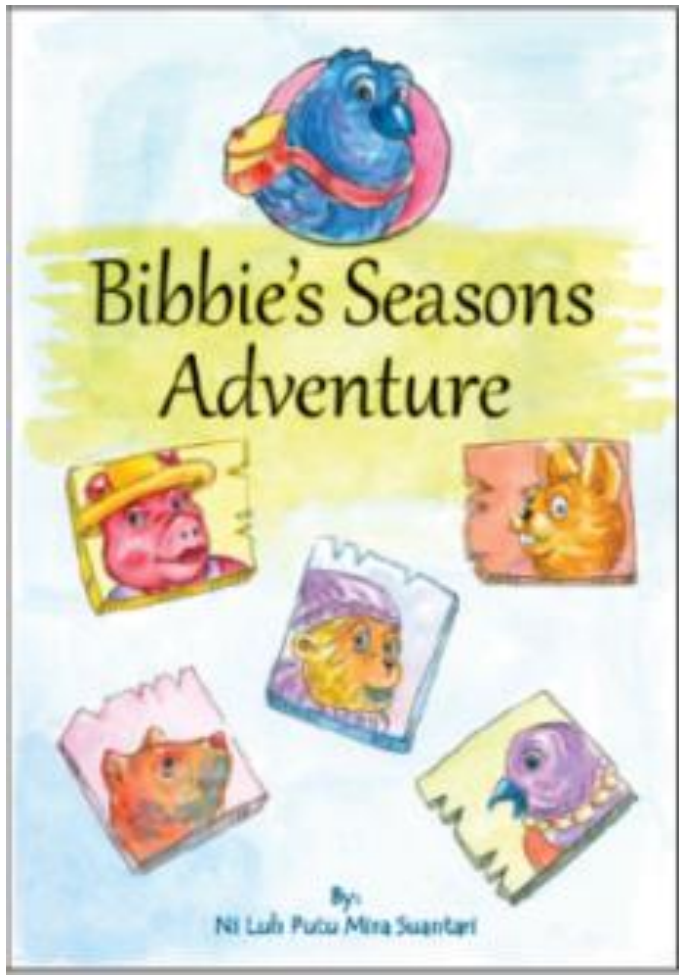

Picture 1. The Cover of The Big Book

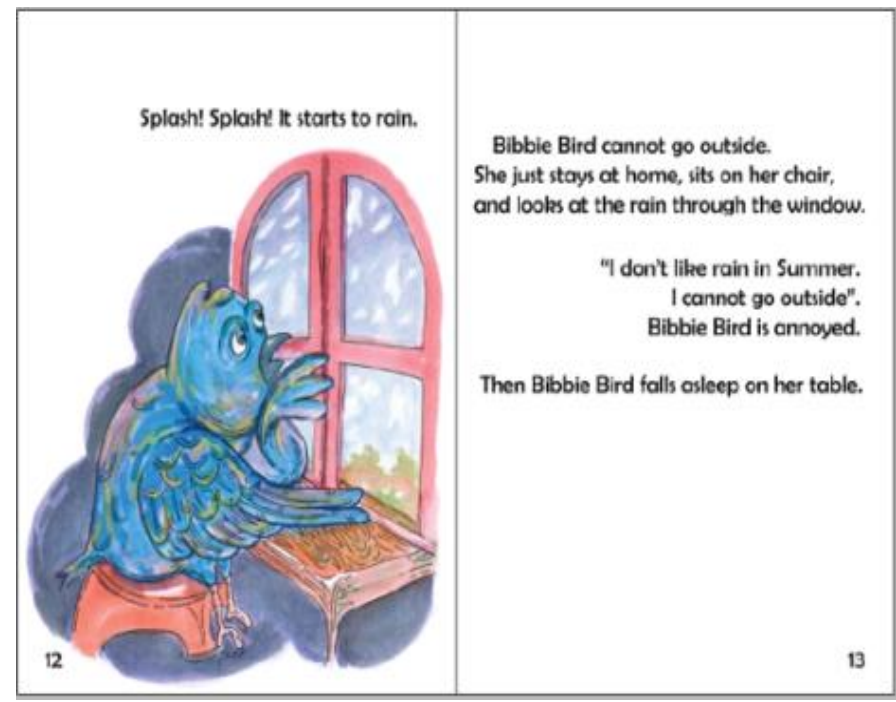

Picture 2. Example of Pages in the Big Book

The third activity was re-reading activity. In this activity, the researcher repeated the story page by page and sometimes stopped in a certain page if there was difficult word that the students did not understand. The researcher showed the words and said it clearly to the students. Showing the words to the students made them familiar with the meaning of the words and it helped the students in comprehending the story. The researcher asked the students to comment on the story and stopped for awhile in the certain page to give chance to the students to guess the next story. Moreover, the researcher also 
gave some questions to the students related to the story in the Big Book in order to help the students in comprehending the story.

The fourth activity was after reading activity. In this activity, the researcher discussed the keyword in the story and helped the students to connect one concept with another concept. It was done by relating their own experiences to the meaning of the story as well as their own language to the text indicated comprehension both the story and the function of the text. Then, the researcher and the students read the story together. This was in line with Hall \& O'Connor who state that using the big book in the classroom usually involves a shared reading experience [16]. Sugara defines shared reading as an interactive reading experience that occurs when students join in or share the reading of a big book while guided and supported by a teacher or other experienced reader [22]. By using Big Book in shared reading activity the students were able to see the text while it was being pointed to and read by the teacher. They also could discuss the meaning of the story with their friends. Furthermore, the researcher told the students randomly to read the story in front of the class.

The last activity was close activity. In this activity, the researcher gave some interesting activities to the students to check the students' reading comprehension of the story such as by giving guessing word game for the first Big Book, matching game for the second Big Book, arranging a game and completing the missing words game for the third Big Book. In this activity, the students were very active to do the activities given by the researcher. They enjoyed the learning activities in the classroom. The example of the activity can be seen in picture 3 .

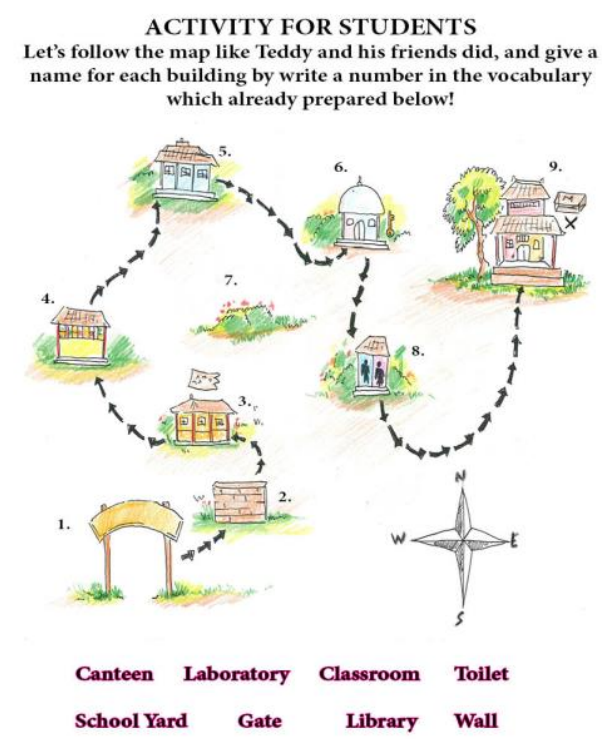

Picture 3. Example of Activity after Reading

The result of this study indicated that applying Big Book as media in teaching reading comprehension to the sixth-grade students was very helpful. There were some factors which were made Big Book as media helpful for students' reading comprehension rather than conventional media. First, students who were taught by using Big Book as media became more active during the reading class activity rather than students taught by conventional media. Second, Big Book attracted students' attention and encouraged students to read more. Third, Big Book helped the students to construct the meaning of the text and it led them to have a deeper understanding of the text given.

Big Book was effective because students became more active in the teaching and learning process. There were some activities done in applying Big Book as media in teaching reading comprehension and the students were involved in the learning process from the beginning until the end of the activities. In each activity, the students actively asked some questions related to the story and sometimes they asked about difficult words that they found from the Big Book. Moreover, the students also answered the questions enthusiastically. It was in line with the statement by Fahmi, et.al. who state that one of the benefits of Big Book was increased students' participation in reading class activity [18]

Big Book attracted students' attention and encouraged students to read more because of the unusual size of the Big Book and the colorful illustration of the Big Book. As the subject of this study was still categorized as young learners and as one the characteristics of young learners who had limited attention span and they were easy to get bored [11], Big Book was a great media used in attracting students' attention and made them not feel bored by seeing the illustration of the story and it led the students to read more. From the beginning of the lesson, the students gave their full attention to the Big Book. It was in line with the statement by Fahmi, et.al. who state that another benefits of Big Book was improved students' attention and attracted young children curiosity as well as sustained their enthusiasm [18]. Moreover, reading a Big Book is one of the activities that encourage the students to read [17]

Actually, there are some points that should be considered in teaching reading for young learners [12]. One of them was using media. Media helped to create a good classroom situation and media also can be used to help the students in comprehending the material given easily [12]. It was proven in this research in which Big Book as media helped the students to construct the meaning of the text and it led them to have a deeper understanding of the text given. It is because Big Book is big on pictures which assist the students in constructing the meaning of the text [16]. Therefore, students' reading comprehension was developed during the treatment. Reading a Big Book facilitate students' comprehension of a story and enhanced comprehension of texts [17].

To sum up, considering the result of the study, it could be concluded that Big Book as media has been proven effective for teaching reading. It was found effective to be applied for the sixth students of SD Laboratorium Undiksha Singaraja The result of this study supported the findings of some 
empirical studies like Tatminingsih in 2013 who found that all children had a good improvement in their reading readiness by using Big Book. Moreover, this current study was also in line with Fahmi et al., in 2013 who found out that Big Book could improve fifth-grade students' reading comprehension. They added that big book also offered a new way in developing students' literacy as well as enhanced comprehension of texts.

\section{CONCLUSION AND SUGGESTIONS}

Referring the result that has been presented in the previous chapter, it could be concluded that the use of Big Book as media for teaching reading comprehension of the sixth-grade students was very helpful for students' reading comprehension achievement. Moreover, Big Book also gave some advantages for the students such as Big Book was useful for teaching young learners because it could attract students' attention because of the size of the Big Book. Big Book helped the students to construct the meaning of the text and it led them to have a deeper understanding of the text given. Big Book also encouraged the students to read more and the students' participation increase in the learning process. Furthermore, the result of this study also support the other research that stated Big Book as media have significant effect to the students' reading comprehension, This proves that Big Book as a media is a good thing to be implemented in the classroom learning process.

Based on the research findings, there are several things that the researcher would like to suggest to readers. Specifically, the suggestions were addressed to English teachers and other researchers because it was found that Big Book as media effects better than conventional media on the sixth-grade students of SD Laboratorium Undiksha Singaraja, English teacher should take this finding as a consideration when they teach reading to the students. It has been proven empirically that this media is effective to be used to improve students' reading comprehension. For other researchers who are interested to conduct similar research, it is suggested to improve it by conducting similar research on larger and different population and used many kinds of Big Book. It is also suggested in doing deep analysis in order to find out another benefit that Big Book can give a good effect to the students' reading comprehension.

\section{REFERENCES}

[1] N. M. Nurpratiwi, L. P. Artini, and A. A. I. N. Marhaeni, "Developing Rich Language Learning Environment To Support Sixth Grade Student's English Literacy Skills," e-Journal Progr. Pascasarj. Univ. Pendidik. Ganesha, vol. 1, 2013.

[2] E. M. K. Gawi, "The Effects of Age Factor on Learning English : A Case Study of Learning English in Saudi Schools , Saudi Arabia," English Lang. Teach., vol. 5, no. 1, 2012.

[3] C. T. Mart, "Encouraging Young Learners to Learn English through Stories," English Lang. Teach., vol. 5, no. 5, 2012.

[4] H. S. Alyousef, "Teaching Reading Comprehension to ESL / EFL Learners," J. Lang. Learn., vol. 5, no. 1, 2006.
[5] W. Grabe, Reading in a Second Language: Moving from Theory to Practice. United State of America: Cambridge University Press, 2009.

[6] P. Aghasafari and F. A. Malayeri, "Improving students' reading comprehension through text structure," Int. J. Educ. Investig., vol. 2, no. 3, pp. 148-158, 2015.

[7] J. K. Klingner, S. Vaughn, and A. Boardman, Teaching reading comprehension to students with learning difficulties. New York: The Guilford Press, 2007.

[8] J. C. Alderson, Assessing Reading. United Kingdom: Cambridge University Press, 2000.

[9] G. Wainwright, How to Read Faster and Recall More, Third. United Kingdom: How To Books, 2007.

[10] J. K. Shin, "Ten Helpful Ideas for Teaching English to Young Learners," English Teach. Forum, vol. 44, no. 2, 2007.

[11] J. Harmer, The Practice of English Language Teaching, 4th ed. Cambridge: Pearson Education, 2007.

[12] Sukarno, "Teaching English To Young Learners And Factors To Consider In Designing The Materials," J. Ekon. Pendidik., vol. 5, no. 1,2008

[13] W. N. Aini, "Instructional Media in Teaching English to Young Learners: A Case Study in Elementary Schools in Kuningan," J. English Educ., vol. 1 , no. 1,2013

[14] A. A. Naz and R. A. Akbar, "Use of Media for Effective Instruction its Importance: Some Consideration," J. Elem. Educ., vol. 18, no. 1-2, 2008.

[15] N. Loukia, "The Reading Matrix Vol. 6, No. 1, April 2006," Read. Matrix, vol. 6, no. 1, 2006.

[16] S. C. Hall and B. O'Connor, "Using Big Books: A Standards-Based Instructional Approach for Foreign Language Teacher Candidates in a PreK-12 Program," Foreign Lang. Anal., vol. 39, no. 3, 2006.

[17] N. A. Rahim and N. I. Harun, "Students ' Perception Towards The Usage of the Big Book," Gading Bus. Manag. J., vol. 14, 2010.

[18] D. I. Fahmi, L. Suhartono, and Z. Arifin, "Improving students' reading comprehension using big book," Tanjungpurna University Pontianak, 2013.

[19] S. Tatminingsih, "International Conference On Educational Research and Innovation," in Big Book, A Teaching Alternative For Improving Children's Reading Readiness In Kindergarten, 2013

[20] N. L. P. M. Suantari, "Developing Character Based Big Book As A Media For Teaching English At Sixth Grade Students of Elementary School At SD Lab UNDIKSHA Singaraja," Ganesha University of Education, 2016.

[21] N. K. Nambiar, "Big Book for Little Readers: Works in the ESL Classroom Too.," 1991.

[22] Y. Sugara, "The Effect of Using Shared Reading Strategy Toward Reading Comprehension of the Second Year Studnets At State Senior High School 12 Pekanbaru," State Islamic Unversity of Sultan Syarif Kasim Riau, 2013. 